\title{
NATURE OF ANAEMIA IN RHEUMATOID ARTHRITIS XI. CHANGES IN IRON METABOLISM INDUCED BY THE
ADMINISTRATION OF CORTICOTROPHIN
}

\author{
BY
}

\author{
A. G. MOWAT, T. E. HOTHERSALL, AND W. R. C. AITCHISON \\ From the Rheumatic Diseases Unit, Northern General Hospital, Edinburgh
}

Moderate anaemia of a hypochromic, normocytic type is a common feature of rheumatoid arthritis and disturbance of iron metabolism is a prominent feature of this anaemia. Several previous reports in this series have described abnormalities in the metabolism of iron in this disease (Roy, Alexander, and Duthie, 1955; Richmond, Gardner, Roy, and Duthie, 1956; Richmond, Roy, Gardner, Alexander, and Duthie, 1958; Gardner and Roy, 1961; Owen and Lawson, 1966; Lawson, Owen, and Mowat, 1967), and the present state of knowledge has been reviewed by Mowat and Hothersall (1968). The plasma iron is low in the presence of active disease (Bruzzone and Massimello, 1940; Nilsson, 1948), and the level is well correlated to the activity of the disease (Engstedt and Strandberg, 1966).

When the activity of the rheumatoid arthritis is suppressed with corticotrophin or corticosteroids, some aspects of the abnormal metabolism of iron are corrected. An improvement in haemoglobin concentration and plasma iron values has been reported (Hench, Kendall, Slocumb, and Polley, 1949; Fladee, Newns, Smith, and West, 1959; M.R.C. Report, 1959; Strandberg, 1966). The rapid clearance from the plasma of iron given by intravenous injection is restored to the pattern found in healthy controls (personal observations). Owen and Lawson (1966) reported a diminished release of endogenous iron from senescent red cells in patients with rheumatoid arthritis. The abnormality was corrected by the administration of corticosteroids.

Richmond and others (1956), using the Prussian blue method, found no stainable iron in the bone marrow of 31 per cent. of patients with rheumatoid arthritis. It is well recognized that only iron in the form of haemosiderin will be detected in this way. In the synthesis of haemoglobin, iron from both ferritin and haemosiderin is utilized (Shoden, Gabrio, and Finch, 1953). It is thus necessary to estimate the total quantity of iron in the bone marrow in any study of iron utilization or storage by the bone marrow. Kerr (1957) has shown that the iron content of the bone marrow in patients with anaemia associated with rheumatoid arthritis is significantly less than that in non-anaemic controls, but not as low as that found in patients with iron deficiency anaemia.

The present study was undertaken to assess the effect of corticotrophin on plasma iron values, the urinary excretion of iron, the haemoglobin concentration, and the iron content of the bone marrow in patients with rheumatoid arthritis.

\section{Material}

Patients with Rheumatoid Arthritis (Table I, overleaf)

This group consisted of thirteen patients (4 males and 9 females), whose average age was $52 \cdot 3$ years. All had classical or definite rheumatoid arthritis according to the diagnostic criteria of the American Rheumatism Association (Ropes, Bennett, Cobb, Jacox, and Jessar, 1959). The patients were admitted to the Rheumatic Diseases Unit, Northern General Hospital, Edinburgh, and during the study all received the same basic treatment of rest in bed, splintage, aspirin, and physiotherapy. The patients received 20 i.u. corticotrophin daily by intramuscular injection at 9.00 a.m. Most of the patients were given a 14-day course, but Cases 4, 6, and 8 received only 7 days of treatment. No iron was administered during the period of the study.

\section{Control Subjects (Table II, overleaf)}

This group consisted of five healthy, non-anaemic subjects (4 males and 1 female) whose average age was 43.8 years. Each subject received 20 i.u. corticotrophin by intramuscular injection for two successive days. The potency of the hormone was checked by showing a substantial rise in the plasma cortisol level one hour after the injections. 
HAEMOGLOBIN AND PLASMA AND URINARY IREIN

\begin{tabular}{|c|c|c|c|c|c|c|c|c|c|}
\hline \multirow{2}{*}{$\begin{array}{l}\text { Case } \\
\text { No. }\end{array}$} & \multirow{2}{*}{$\underset{\text { (yrs) }}{\text { Age }}$} & \multirow{2}{*}{ Sex } & \multicolumn{3}{|c|}{ Haemoglobin (g./100 ml.) } & \multicolumn{3}{|c|}{$\operatorname{ESR}(\mathrm{mm} . / 1 \mathrm{hr})$} & \multirow{2}{*}{ MCHG } \\
\hline & & & Basal & Day 7 & Day 14 & Basal & Day 7 & Day 14 & \\
\hline 1 & 43 & $\mathbf{M}$ & $11 \cdot 5$ & $12 \cdot 8$ & $12 \cdot 8$ & 66 & 15 & 9 & $30 \cdot 0 \underline{\bar{c}}$ \\
\hline 2 & 51 & $\mathbf{M}$ & $9 \cdot 3$ & $11 \cdot 2$ & $12 \cdot 2$ & 77 & 43 & 14 & 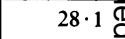 \\
\hline 3 & 53 & $\mathbf{M}$ & $11 \cdot 0$ & $13 \cdot 2$ & $15 \cdot 0$ & 54 & 12 & 3 & $27 \cdot 5 \frac{\Omega}{c}$ \\
\hline 4 & 70 & $\mathbf{M}$ & $10 \cdot 2$ & $10 \cdot 9$ & - & 48 & 6 & - & $31 \cdot 4$ \\
\hline 5 & 44 & $F$ & $8 \cdot 6$ & $8 \cdot 3$ & $10 \cdot 3$ & 32 & 15 & 3 & $24 \cdot 4=$ \\
\hline 6 & 49 & $F$ & $9 \cdot 5$ & $9 \cdot 8$ & - & 75 & 18 & - & $30 \cdot 0$ \\
\hline 7 & 51 & $\mathrm{~F}$ & $8 \cdot 1$ & $8 \cdot 2$ & $8 \cdot 4$ & 61 & 6 & 8 & $26 \cdot 5$ \\
\hline 8 & 63 & $\mathbf{F}$ & $9 \cdot 0$ & $10 \cdot 6$ & - & 28 & 15 & - & $29 \cdot 4$ \\
\hline 9 & t 8 & $\mathbf{F}$ & $8 \cdot 6$ & $10 \cdot 5$ & $10 \cdot 1$ & 90 & 23 & 12 & 29.0 \\
\hline 10 & 31 & $F$ & $7 \cdot 2$ & $8 \cdot 7$ & $9 \cdot 6$ & 107 & 71 & 51 & $28.0 \mathrm{C}$ \\
\hline 11 & 44 & $\mathbf{F}$ & $10 \cdot 4$ & $11 \cdot 7$ & $12 \cdot 6$ & 50 & 14 & 5 & $31 \cdot 0$ \\
\hline 12 & 53 & $\mathrm{~F}$ & $11 \cdot 6$ & $12 \cdot 9$ & $13 \cdot 8$ & 62 & 5 & 6 & $32 \cdot 0$ \\
\hline 13 & 60 & $\mathbf{F}$ & $11 \cdot 6$ & $12 \cdot 4$ & $13 \cdot 0$ & 38 & 35 & 10 & $31 \cdot 0 \leq$ \\
\hline Mean .. & . & . & $9 \cdot 73$ & $10 \cdot 86$ & $11 \cdot 78$ & - & - & - & - \\
\hline
\end{tabular}

\section{Methods}

The haemoglobin was measured against a cyanhaemoglobin standard $(100$ per cent. $=14.6 \mathrm{~g} . / 100 \mathrm{ml}$. $)$ in an "EEL" haemoglobinometer. The erythrocyte sedimentation rate (ESR) was measured by the Westergren method modified by Dawson (1960). Plasma and urinary iron was measured by the method of Ramsay (1957). The total iron content of samples of bone marrow was measured by the method of Kerr (1957). All samples for iron estimations were collected in ironfree vessels.

\section{Blood Indices}

The haemoglobin concentration and the ESR were measured in the patients with rheumatoid arthritis before and after 7 and 14 days of treatment with corticotrophin. The initial mean corpuscular haemoglobin concentration (MCHC) was also estimated.

\section{Plasma Iron}

The basal 9.00 a.m. and 3 p.m. values of the plasma iron were measured in nine patients with rheumatoid arthritis and in all controls. In patients the plasma iron was measured $6,24,48$, and 72 hours and 7 and 14 days after the start of treatment with corticotrophin. In controls the measurements were made after 6,24 , and 48 hours. All measurements were made at 9.00 a.m. unless otherwise stated.

\section{Urinary Excretion of Iron}

The 24-hour urinary excretion of iron was measured in nine patients with rheumatoid arthritis and all the controls. Collections were made before treatment and for 2 days in controls and for 3 days in patients after the start of corticotrophin administration.

TABLE II

PLASMA AND URINARY IRON IN FIVE CONTROLS

\begin{tabular}{|c|c|c|c|c|c|c|c|c|c|c|}
\hline \multirow{2}{*}{$\begin{array}{l}\text { Case } \\
\text { No. }\end{array}$} & \multirow{2}{*}{$\begin{array}{c}\text { Age } \\
\text { (yrs) }\end{array}$} & \multirow{2}{*}{ Sex } & \multicolumn{5}{|c|}{ Plasma Iron $(\mu \mathrm{g} . / 100 \mathrm{ml})}$. & \multicolumn{3}{|c|}{ 24-hr Urinary Iron $(\mu \mathrm{g})}$. \\
\hline & & & Basal 9 a.m. & Basal 3 p.m. & $6 \mathrm{hrs}$ & $24 \mathrm{hrs}$ & $48 \mathrm{hrs}$ & Basal & Day 1 & Day 2 \\
\hline 1 & 43 & $\mathbf{F}$ & 115 & 90 & 92 & 116 & 120 & 750 & 684 & 648 \\
\hline 2 & 30 & $\mathbf{M}$ & 131 & 94 & 98 & 132 & 120 & 276 & 263 & 269 \\
\hline 3 & 42 & $\mathbf{M}$ & 129 & 106 & 104 & 128 & 132 & 300 & 281 & 269 \\
\hline 4 & 43 & $\mathbf{M}$ & 122 & 84 & 86 & 126 & 126 & 302 & 312 & 321 \\
\hline 5 & 61 & $\mathbf{M}$ & 80 & 62 & 60 & 72 & 74 & 466 & 310 & 342 \\
\hline Mean & & & $115 \cdot 4$ & $87 \cdot 2$ & $88 \cdot 0$ & $114 \cdot 8$ & $114 \cdot 4$ & $418 \cdot 8$ & $370 \cdot 0$ & $369 \cdot 8$ \\
\hline
\end{tabular}


IN PATIENTS WITH RHEUMATOID ARTHRITIS

\begin{tabular}{|c|c|c|c|c|c|c|c|c|c|c|c|}
\hline \multicolumn{8}{|c|}{ Plasma Iron $(\mu \mathrm{g} . / 100 \mathrm{ml})}$. & \multicolumn{4}{|c|}{ 24-hr Urinary Iron ( $\mu \mathrm{g}$.) } \\
\hline $\begin{array}{l}\text { Basal } \\
9 \text { a.m. }\end{array}$ & $\begin{array}{l}\text { Basal } \\
\text { 3 p.m. }\end{array}$ & $6 \mathrm{hrs}$ & $24 \mathrm{hrs}$ & $48 \mathrm{hrs}$ & $72 \mathrm{hrs}$ & Day 7 & Day 14 & Basal & Day 1 & Day 2 & Day 3 \\
\hline 23 & 19 & 34 & 78 & 102 & 124 & 130 & - & 532 & 520 & 731 & 704 \\
\hline 22 & 26 & 60 & 80 & 78 & 74 & 80 & 64 & 450 & 582 & 745 & 553 \\
\hline 28 & 28 & 32 & 82 & 106 & 100 & 100 & 114 & 380 & 656 & 582 & 563 \\
\hline 38 & 30 & 48 & 90 & 102 & 106 & 82 & - & 403 & 471 & 483 & 374 \\
\hline 19 & 12 & 40 & 92 & 68 & 72 & 70 & - & 357 & 398 & 312 & 341 \\
\hline 32 & 28 & 44 & 70 & 90 & 82 & 88 & - & 484 & 840 & 560 & 385 \\
\hline 25 & 30 & 44 & 50 & 48 & 50 & 42 & 50 & 340 & 468 & 498 & 442 \\
\hline 32 & 26 & 50 & 104 & 116 & 124 & 70 & - & 500 & 464 & 400 & 475 \\
\hline 30 & 32 & 48 & 72 & 80 & 80 & 78 & 56 & 284 & 340 & 346 & 288 \\
\hline 48 & - & - & - & - & 92 & 108 & 102 & 一 & - & - & - \\
\hline 52 & - & - & - & - & 146 & 122 & 120 & - & - & - & - \\
\hline 28 & - & - & - & - & 104 & 110 & 116 & - & - & - & - \\
\hline 26 & - & - & - & - & 110 & 104 & 100 & - & 一 & - & - \\
\hline $28 \cdot 4$ & $25 \cdot 7$ & $44 \cdot 4$ & $79 \cdot 8$ & $87 \cdot 8$ & $97 \cdot 2$ & $91 \cdot 0$ & $91 \cdot 0$ & $414 \cdot 4$ & $526 \cdot 5$ & $517 \cdot 4$ & $458 \cdot 3$ \\
\hline
\end{tabular}

\section{Bone Marrow Studies}

Samples of bone marrow were aspirated from the sternum in four patients with rheumatoid arthritis before and 7 and 14 days after the start of treatment. Estimations were made of the total iron content of each specimen. In addition, slides of bone marrow stained by the May-Grunwald-Giemsa method were examined to ensure that the anaemia was typical of rheumatoid arthritis. Several slides were stained with acidified potassium ferrocyanide and the amount of ferric-ferrocyanide (Prussian blue) assessed in four grades: $0,+$, ++ and +++ by two observers.

\section{Results}

\section{Haemoglobin Concentration and ESR}

The results are set out in Table $I$ and Fig. 1. There was a mean increase of $2.05 \mathrm{~g} . / 100 \mathrm{ml}$. in haemoglobin concentration over the 14-day period. In every case there was a substantial fall in the ESR indicating a reduction in the activity of the disease.

\section{Plasma Iron}

The results for patients are set out in Table I and for controls in Table II. The results are compared in Fig. 2 (overleaf). The pre-treatment values of the plasma iron show the normal diurnal variation in both groups with the lower value at 3 p.m. This diurnal variation was more marked, and the corticotrophin produced no significant change, in the plasma iron

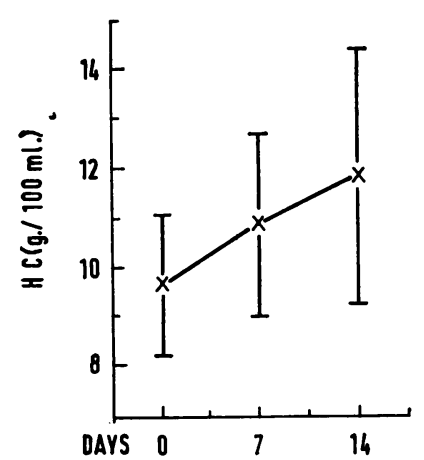

Fig. 1.-Effect of corticotrophin on haemoglobin concentration in patients (mean values with standard deviation).

values in controls. In patients there was a mean rise of $18.7 \mu \mathrm{g} . / 100 \mathrm{ml}$. 6 hours after the first injection of corticotrophin. The plasma iron continued to rise with a mean increase of $68 \cdot 8 \mu \mathrm{g}$./ $100 \mathrm{ml}$. after 72 hours, and the elevation of plasma iron was maintained during the first and second weeks of treatment. The smallest rises were seen in Cases 5 and 7, in whom the initial MCHC suggested that there was some element of iron deficiency anaemia.

\section{Urinary Excretion of Iron}

The results of the estimation of the 24-hour urinary excretion of iron for patients are set out in 


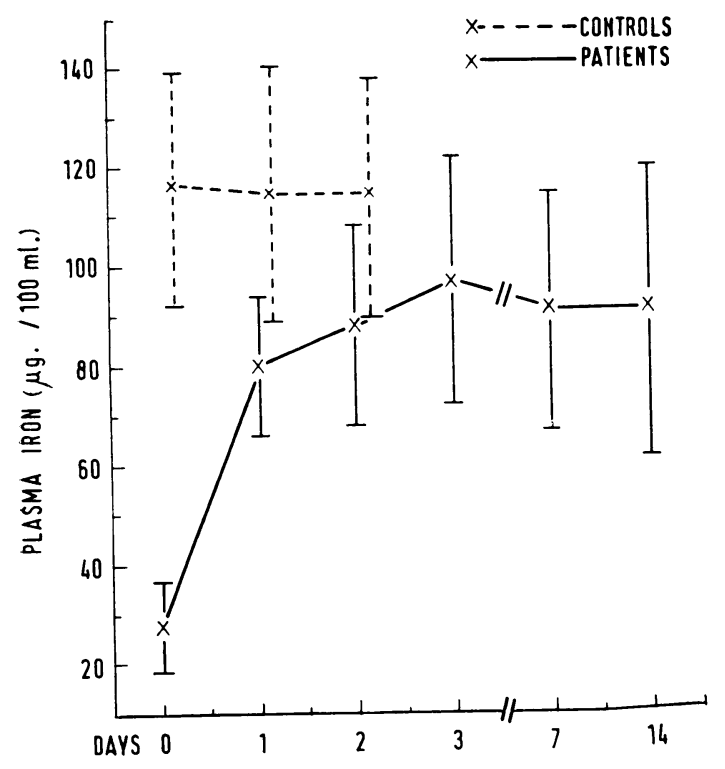

Fig. 2.-Effect of corticotrophin on plasma iron values in patients and controls (mean 9 a.m. values with standard deviation).

Table I, and for controls in Table II. The results are compared in Fig. 3. There was no significant difference in the results for the two groups and corticotrophin did not significantly influence the amount of iron in the urine.

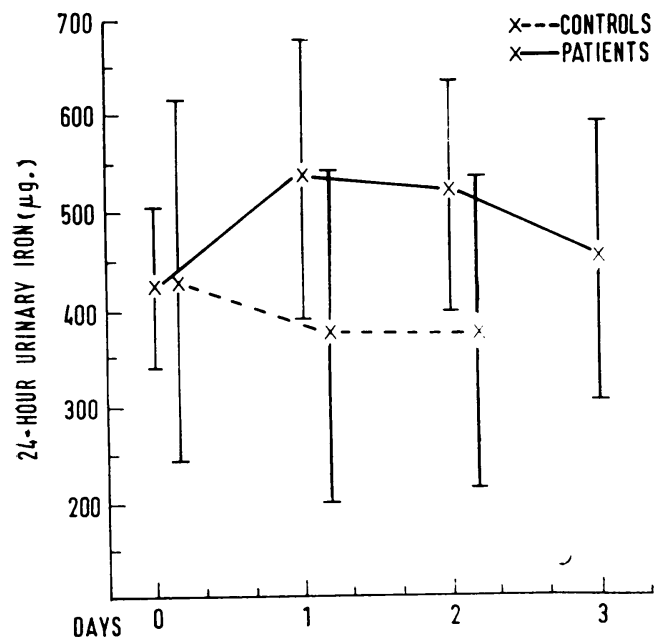

Fig. 3.-Effect of corticotrophin on urinary iron excretion in patients and controls (mean values with standard deviation).

\section{Iron Content of Bone Marrow}

The results of estimation of the total iron content of the bone marrow expressed as $\mu \mathrm{g}$. $/ 100 \mathrm{mg}$. protein and the qualitative grading of the Prussian blue staining of slides of bone marrow are shown in Table III and Fig. 4. After 7 days' treatment with corticotrophin, the mean value of the total iron content of the marrow had risen by $54 \cdot 5 \mu \mathrm{g}$. $/ 100 \mathrm{mg}$. protein, with a further increase of $136 \cdot 0 \mu \mathrm{g}$. $/ 100 \mathrm{mg}$. protein by Day 14. The Prussian blue method of staining detects iron only in the form of haemosiderin and the grading cannot be correlated with the chemical estimations. In three cases the administration of corticotrophin reduced the amount of haemosiderin.

TABLE III

MARROW IRON CONTENT IN FOUR PATIENTS WITH RHEUMATOID ARTHRITIS

\begin{tabular}{|c|c|c|c|c|c|c|}
\hline \multirow{3}{*}{$\begin{array}{c}\text { Case } \\
\text { No. }\end{array}$} & \multicolumn{6}{|c|}{$\begin{array}{l}\text { Marrow Iron Content ( } \mu \mathrm{g} . / 100 \mathrm{mg} \text {. protein) } \\
\text { and Staining Reaction }(0,+,++,+++)\end{array}$} \\
\hline & \multicolumn{2}{|c|}{ Basal } & \multicolumn{2}{|c|}{ Day 7} & \multicolumn{2}{|c|}{ Day 14} \\
\hline & $78 \cdot 3$ & ++ & $137 \cdot 9$ & ++ & $285 \cdot 7$ & + \\
\hline 11 & $45 \cdot 1$ & + & $80 \cdot 0$ & 0 & $195 \cdot 9$ & 0 \\
\hline 12 & $65 \cdot 9$ & + & $123 \cdot 3$ & + & $295 \cdot 7$ & + \\
\hline 13 & $67 \cdot 7$ & + & $134 \cdot 2$ & 0 & $242 \cdot 0$ & 0 \\
\hline Mean & $64 \cdot 25$ & & $118 \cdot 8$ & & $254 \cdot 8$ & \\
\hline
\end{tabular}

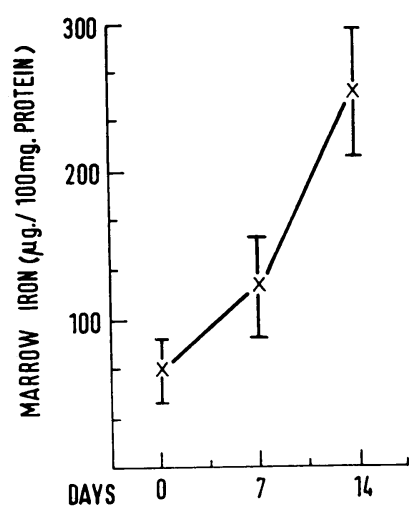

Fig. 4.-Effect of corticotrophin on bone marrow iron content in patients (mean values with standard deviation).

\section{Discussion}

Although disturbance of iron metabolism is a prominent feature of the anaemia of rheumatoid arthritis, there is no evidence that there is a deficiency of iron. There is no significant increase in the plasma iron-binding capacity (Jeffrey, 1953; Roy and others, 1955), and the MCHC is only a little below normal (Richmond and others. 1958). Roy and others (1955) and Weinstein (1959) demonstrated no abnormality in the absorption of iron from the gut in patients with rheumatoid arthritis, although Raymond, Bowie, and Dugan (1965) 
suggested that there was mild impairment. Lawson and others (1967) showed that there was increased iron excretion in the urine in patients with rheumatoid arthritis compared with controls after the administration of the chelating agent Desferrioxamine B. It was considered that these results provided evidence of increased iron storage in these patients. Mowat and Hothersall (1968) and Senator and Muirden (1968) have shown considerably higher concentrations of iron in the synovial tissue of patients with rheumatoid arthritis compared with controls. Since there is proliferation of synovial tissue in patients with rheumatoid arthritis, it follows that relatively large quantities of iron must be deposited in this tissue. No evidence of large iron stores in other sites has been found in these patients (Gardner and Roy, 1961). This retention of iron by synovial tissue would appear to take place during episodes of active inflammation, since plasma iron values return to normal when activity of the disease is suppressed by administration of corticotrophin.

The very rapid restoration of plasma iron to normal levels has only been reported once in patients with rheumatoid arthritis (Whittingham, Balazs, and Mackay, 1967). These authors suggested that plasma iron might be a useful index of activity of the disease, since the return of plasma iron to normal values precedes the fall of the ESR. The diurnal variation in plasma iron levels in healthy controls resulting in up to 50 per cent. differences between morning and afternoon values reported by Hamilton, Gubler, Cartwright, and Wintrobe (1950) is confirmed, although the variation is much smaller in the patients with rheumatoid arthritis. The variation in plasma iron levels lags some 2 hours behind the diurnal variation in 17-hydroxycorticosteroid and is almost certainly an independent phenomenon (Migeon, Tyler, Mahoney, Florentin, Castle, Bliss, and Samuels, 1956). This is supported by the failure of corticotrophin or corticosteroid therapy to alter the basal values or diurnal variation of plasma iron in controls in this or other studies (Sayers, Burns, Tyler, Jager, Schwartz, Smith, Samuels, and Davenport, 1949).

There was no significant difference in the 24-hour urinary excretion of iron in the two groups. Thus, despite low plasma iron levels there was no reduction in the urinary loss of iron in patients with rheumatoid arthritis such as occurs in patients with iron-deficiency anaemia (Dagg, Smith, and Goldberg, 1966). Corticotrophin did not alter significantly the urinary excretion of iron. Despite the large rise in plasma iron values in the patients with rheumatoid arthritis, there was no overflow of iron into the urine.
The only consistent abnormality in the cellular content of the bone marrow in patients with rheumatoid arthritis is a moderate hyperplasia of elements of the reticulo-endothelial system, especially plasma cells (Richmond and others, 1956). This is corrected by steroid therapy as shown in this and other studies (Berglund, Nordenson, and Olhagen, 1951). The iron content of bone marrow in our patients before treatment with corticotrophin $(64 \cdot 3 \mu \mathrm{g} . / 100 \mathrm{mg}$. protein) is close to the mean value of $55.0 \mu \mathrm{g} . / 100 \mathrm{mg}$. protein for patients with rheumatoid arthritis, but below the mean value of $86.0 \mu \mathrm{g} . / 100 \mathrm{mg}$. protein for non-anaemic control subjects reported by Kerr (1957). There was a progressive increase in the iron content of bone marrow during 14 days of treatment with corticotrophin. At the same time there was a reduction in the quantity of haemosiderin in the bone marrow as shown by the Prussian blue staining reaction. The only other report of the effect of steroid therapy on the iron content of bone marrow in patients with rheumatoid arthritis recorded a reduction in both haemosiderin and total iron content, but measurements were made only before and after 6 weeks of treatment (Strandberg, 1966).

Iron stored as either ferritin or haemosiderin is used in the bone marrow for haemoglobin formation (Shoden and others, 1953). After 14 days of treatment with corticotrophin the mean corpuscular haemoglobin concentration had risen by $2.05 \mathrm{~g} . /$ $100 \mathrm{ml}$. Presumably the iron released from the synovial membrane and the other smaller iron stores when the activity of the disease is suppressed is stored as ferritin.

\section{Summary}

(1) The changes in iron metabolism induced by administration of corticotrophin in thirteen patients with rheumatoid arthritis and five healthy controls have been studied.

(2) No change in plasma iron values or 24-hour urinary excretion of iron was found in the controls given corticotrophin for 2 days.

(3) There was very rapid correction of the low plasma iron values in the patients given corticotrophin and the elevation of plasma iron was maintained throughout the period of treatment.

(4) There was a mean rise in haemoglobin concentration of $2.05 \mathrm{~g} . / 100 \mathrm{ml}$. after 14 days of treatment in the patients without the addition of any haematinic.

(5) There was a progressive increase in the total iron content of the bone marrow with treatment in 
four patients. At the same time there was a reduction in the haemosiderin content of the marrow as shown by the Prussian blue staining reaction. The cellular content of the bone marrow returned to normal.

(6) There was no difference in 24-hour urinary excretion of iron in patients compared with controls, and corticotrophin did not alter this excretion.

(7) The abnormalities in metabolism of iron in patients with rheumatoid arthritis are discussed in the light of these findings.
We wish to thank Prof. J. J. R. Duthie and Dr. W. R. M. Alexander of the Rheumatic Diseases Unit, Northern General Hospital, Edinburgh, for permission to study their patients and for their encouragement and helpful advice throughout the period of study. We are indebted to Dr. N. C. Allan of the Haematology Department, Western General Hospital, Edinburgh, for his guidance in the bone marrow studies. We also wish to thank Sister Daniel for her assistance with the collection of specimens and Mr. H. J. Rylance, B.Sc., and Mrs. D. Bertram for their help with the chemical estimations.

During the period of study the Rheumatic Diseases Unit was in receipt of grants from the Arthritis and Rheumatism Council, the Nuffield Foundation, and Boots Pure Drug Company Limited.

\section{REFERENCES}

Berglund, K., Nordenson, N. G., and Olhagen, B. (1951). Acta endocrinol. (Kbh.), 8, 1 (ACTH and cortisone in rheumatoid arthritis. Effects on blood protein pattern, serological reactions and bone marrow reticulum).

Bruzzone, L., and Massimello, F. (1940). Arch. Sci. med., 69, 236 (Studi sulla determinazione del ferro e del rame totale nel sangue in varie condizioni morbose).

Dagg, J. H., Smith, J. A., and Goldberg, A. (1966). Clin. Sci., 30, 495 (Urinary excretion of iron).

Dawson, J. B. (1960). Brit. med. J., 1, 1697 (The ESR in a new dress).

Engstedt, L., and Strandberg, O. (1966). Acta med. scand., Suppl. 454, p. 13 (Haematological data and clinical activity of the rheumatoid disease).

Fladee, H. W., Newns, G. R., Smith, W. D., and West, H. F. (1959). Ann. rheum. Dis., 18, 120 (Trials of cortisone analogues in the treatment of rheumatoid arthritis).

Gardner, D. L., and Roy, L. M. H. (1961). Ibid., 20, 258 (Tissue iron and the reticulo-endothelial system in rheumatoid arthritis).

Hamilton, L. D., Gubler, C. J., Cartwright, G. E., and Wintrobe, M. M. (1950). Proc. Soc. exp. Biol. (N.Y.), 75, 65 (Diurnal variation in the plasma iron level of man).

Hench, P. S., Kendall, E. C., Slocumb, C. H., and Polley, H. F. (1949). Proc. Mayo Clin., 24, 181 (The effect of a hormone of the adrenal cortex (17-hydroxy-11-dehydrocorticosterone: compound E) and of pituitary adrenocorticotropic hormone on rheumatoid arthritis: Preliminary report).

Jeffrey, M. R. (1953). Blood, 8, 502 (Some observations on anaemia in rheumatoid arthritis).

Kerr, L. M. H. (1957). Biochem. J., 67, 627 (A method for the determination of non-haem iron in bone marrow).

Lawson, A. A. H., Owen, E. T., and Mowat, A. G. (1967). Ann. rheum. Dis., 26, 552 (Nature of anaemia in rheumatoid arthritis. VII. The storage of iron in rheumatoid disease).

Migeon, C. J., Tyler, F. H., Mahoney, J. P., Florentin, A. A., Castle, H., Bliss, E. L., and Samuels, L. T. (1956). J. clin. Endocr., 16, 622 (The diurnal variation of plasma levels and urinary excretion of 17-hydroxy-corticosteroids in normal subjects, night workers and blind subjects).

Mowat, A. G., and Hothersall, T. E. (1968). Ann. rheum. Dis., 27, 345 (Nature of anaemia in rheumatoid arthritis. VIII. Iron content of synovial tissue in patients with rheumatoid arthritis and in normal individuals).

M. R. C. Report (1959). Ibid., 18, 173 (A comparison of prednisolone with aspirin and other analgesics in the treatment of rheumatoid arthritis).

Nilsson, F. (1948). Acta med. scand., 130, Suppl. 210 (Anaemia problems in rheumatoid arthritis).

Owen, E. T., and Lawson, A. A. H. (1966). Ann. rheum. Dis., 25, 547 (Nature of anaemia in rheumatoid arthritis. VI. Metabolism of endogenous iron).

Ramsay, W. N. M. (1957). Clin. chim. Acta, 2, 214 (The determination of iron in blood plasma or serum).

Raymond, F. D., Bowie, M. A., and Dugan, A. (1965). Arthr. and Rheum., 8, 233 (Iron metabolism in rheumatoid arthritis).

Richmond, J., Gardner, D. L., Roy, L. M. H., and Duthie, J. J. R. (1956). Ann. rheum. Dis., 15, 217 (Nature of anaemia in rheumatoid arthritis. III. Changes in the bone marrow and their relation to other features of the disease). 
-, Roy, L. M. H., Gardner, D. L., Alexander, W. R. M., and Duthie, J. J. R. (1958). Ibid., 17 406 (Nature of anaemia in rheumatoid arthritis. IV. Effects of intravenous administration of saccharated oxide of iron).

Ropes, M. W., Bennett, G. A., Cobb, C., Jacox, R., and Jessar, R. (1959). Ibid., 18, 49 (1958 Diagnostic criteria for rheumatoid arthritis).

Roy, L. M. H., Alexander, W. R. M., and Duthie, J. J. R. (1955). Ibid., 14, 63 (Nature of anaemia in rheumatoid arthritis. I. Metabolism of iron).

Sayers, G., Burns, T. W., Tyler, F. H., Jager, B. V., Schwartz, T. B., Smith, E. L., Samuels, L. T., and Davenport, H. W. (1949). J. clin. Endocr., 9, 593 (Metabolic actions and fate of intravenously administered adrenocorticotropic hormone in man).

Senator, G. B., and Muirden, K. D. (1968). Ann. rheum. Dis., 27, 49 (Concentration of iron in synovial membrane, synovial fluid and serum in rheumatoid arthritis and other joint diseases).

Shoden, A., Gabrio, B. W., and Finch, C. A. (1953). J. biol. Chem., 204, 823 (The relationship between ferritin and hemosiderin in rabbits and man).

Strandberg, O. (1966). Acta med. scand., Suppl. 454, p. 127 (The influence of corticosteroid therapy on hematological values, bone marrow iron and iron absorption in patients with rheumatoid arthritis).

Weinstein, I. M. (1959). Blood, 14, 950 (A correlative study of the erythrokinetics and disturbances of iron metabolism associated with the anaemia of rheumatoid arthritis).

Whittingham, S., Balazs, N. D. H., and Mackay, I. R. (1967). Med. J. Aust., 2, 639 (The effect of corticosteroid drugs on serum iron levels in systemic lupus erythematosus and rheumatoid arthritis).

La nature de l'anémie dans la polyarthrite rhumatoïde. XI. Les changements dans le métabolisme du fer provoqués par l'administration de la corticotrophine

\section{RÉSUMÉ}

(1) Les changements dans le métabolisme du fer provoqués par l'administration de la corticotrophine chez treize malades atteints de polyarthrite rhumatoïde et cinq témoins sains ont été étudiés.

(2) Aucun changement dans le taux du fer du plasma ou dans l'excrétion urinaire de 24 heures n'avait été vu chez témoins recevant la corticotrophine pendant deux jours.

(3) Il y avait en une très rapide correction des taux faibles du fer du plasma des malades recevant de la corticotrophine et l'augmentation du taux du fer du plasma avait été maintenue pendant toute la période de traitement.

(4) Il y avait eu une augmentation, en moyenne, dans la concentration d'hémoglobine de $2,05 \mathrm{~g} . / 100 \mathrm{ml}$. après 14 jours de traitement chez les malades sans l'addition d'aucun agent hématique.

(5) Il y avait une augmentation progressive dans le contenu total de fer dans la moelle des os après traitement chez quatre malades. En même temps il y avait eu une réduction du contenu d'hémosidérine de la moelle comme démontrée par la réaction au colorant du bleu de Prusse. Le contenu des cellules de la moelle des os était retourné à la normale.

(6) Il n'y avait eu aucune différence dans l'excrétion urinaire de 24 heures du fer chez les malades comparée à celle des témoins, et la corticotrophine n'avait pas changé cette excrétion.

(7) Les anomalies dans le métabolisme du fer chez les malades atteints de polyarthrite rhumatoïde sont discutées à la lumière de ces constatations.
Naturaleza de la anemia en la poliartritis reumatoide. XI. Cambios en el metabolismo del hierro inducidos por la administración de corticotropina

\section{SUMARIO}

1. Se han estudiado los cambios en el metabolismo del hierro inducidos por la administración de corticotropina en trece pacientes con poliartritis reumatoide y cinco testigos sanos.

2. No se descubrió ningún cambio en los valores del hierro plasmático ni en la excreción urinaria de hierro en un período de 24 horas en los testigos que habían recibido dosis de corticotropina durante dos días.

3. Hubo una rápida corrección de los valores bajos del hierro plasmático en los pacientes que habían recibido corticotropina, y la elevación del hierro plasmático se mantuvo durante todo el período de tratamiento.

4. Hubo un aumento medio en la concentración hemoglobínica de $2,05 \mathrm{~g}$. $/ \mathrm{ml}$. al cabo de 14 días de tratamiento en los pacientes sin la adición de ningún hematógeno.

5. Hubo un incremento progresivo en el contenido total de hierro de la médula en cuatro pacientes tratados. Al mismo tiempo hubo una reducción en el contenido hemosiderina de la médula, según se probó por la reacción colorante de azúl de Prusia. El contenido celular de la médula retornó a la normalidad.

6. No hubo diferencia en la excreción urinaria de híerro, durante 24 horas, entre pacientes y testigos, y la corticotropina no alteró esta excreción.

7. Las anormalidades en el metabolismo del hierro en los pacientes con poliartritis reumatoide se discuten a la luz de estos hallazgos. 